\title{
Barangay Management Information System (BMIS) for Cities and Municipalities in the Philippines
}

\author{
John Kevin P. Imus \\ San Carlos College \\ Poblacion, Basista \\ Pangasinan
}

\author{
Elmer D. Magleo \\ San Carlos College \\ Agdao, San Carlos City \\ Pangasinan
}

Romulo L. Olalia, Jr.

\author{
Mary Angelica A. Soriano \\ San Carlos College \\ Mangaldan \\ Pangasinan
}

\begin{abstract}
The purpose of this study is to address a solution to the difficulty that has been occurring in a barangay. The idea was to introduce management information system to help solve the problem. This paper provides an efficient and effective way to record and manage information that is needed of every barangay. The Barangay Management Information System is a program which contains features that records and manages information and at the same time can send documents from barangay hall to the city hall.
\end{abstract}

\section{Keywords}

Barangay Clearance. Barangay Management Information System for San Carlos City. Barangay Workers. Barangay Officials. Certificates. Constituents. Information System. IT Equipment. Offline system. Online system. Standard Operating Procedures. System Development Life Cycle (SDLC)

\section{INTRODUCTION}

In this age of advanced technologies of operation, no one is left behind from using high technologies to make works or complex activities easier. Computers, specifically, serve as a general service tools and weapon in the field of information retrieval and operations. Computer-based information retrieval operates through the use of software that can offer information services for an institution or organization. It is powerful and convenient builder for simultaneous growth in society and industries. An information service provides a way to electronically access, retrieve, and transmit that information. San Carlos City is a third class city in the province of Pangasinan. It has 86 barangays and one of these barangays is Barangay Turac. According to the 2010 census, it has a population of 175,103 people, making it the most populated city in Pangasinan and entire Region 1. It is politically subdivided into eighty-six (86) barangays.[1] Barangay Management Information System for San Carlos City is an online and offline system to keep, process, retrieve and update Barangay and City Hall information through a secure network interface. It is designed to handle a wide-range of information relating to barangay profile, constituents profile, barangay clearances, barangay disputes/cases, barangay activities, and barangay legislation and City Hall's required reports from the barangay. It covers all the functions, activities and transactions of the barangay which aims to provide complete and accurate information for the barangay and city hall management and stakeholders.

\subsection{Project Framework}

An Information System is an organized combination of people, hardware, software, resources and communication networks. Information system is also a scientific study that covers strategic, managerial and operational activities. These three activities basically deal with the following operations: (1) Gathering of Information, (2) Processing of Information and (3) Storage of Information.

The framework serves as the basis of the proponents in conducting the study. This included inputs, process and output of the study as shown in Figure 1.

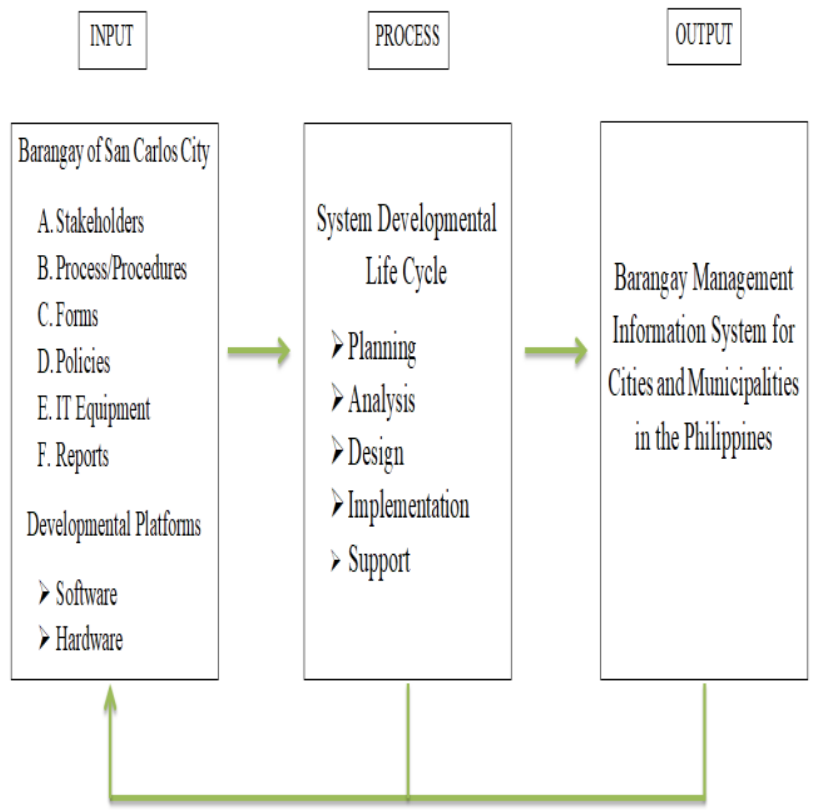

Fig 1: Project Paradigm

\section{REVIEW OF RELATED LITERATURE}

According to Nestor (2016), barangay represent the government at the grass root level. They are considered the epitome of what the government can offer and are the court of first help of the general populace.[2]

Henczel (n.d.) calls this as information audit, focusing on the information sources, resources, show and how information contributes to the objectives of an organization like barangay. This study is the solution to the problems stated and to enhance the quality of service a barangay office offers to its 
clients. Furthermore, this serves as an awakening factor for all government offices, from highest to lowest levels, to be in line with the government's view of globalization and competitiveness in today's information age.[3]

Dr. Peter G. Knight (n.d) in his study, The Online Information System, can stored data, that is, its file or its database, are usually organized in such a way that individual pieces of data can be retrieve and for modified quickly and without necessarily accessing any other piece of data in the system.

The effectiveness is achieved when management style is moving to mutual participation of employers, and enhances the organization to achieve efficiently and effectively its services to the people.

\section{PROJECT DESIGN AND METHODOLOGY}

In designing and developing the proposed system, titled "Barangay Management Information System for Cities and Municipalities in the Philippines", quantitative method will be used in the study. Quantitative research focuses on gathering numerical data and generalizing it across groups of people or to explain a particular phenomenon. The objective of quantitative research is to develop and employ mathematical models, theories and/or hypotheses pertaining to phenomena. The proponents will employ this research method since the study will be conducted by interview, observations, and surveys.

The proponents analyze the design of the proposed study and chose the appropriate methodology as the foundation of the study. There are different types of methodologies that can be used but the proponents will be using of a descriptivedevelopmental method of research in gathering important data on how the system is being presented and designed. Descriptive research method is designed for the proponents to gather information about present existing conditions needed in the chosen field of study.

Descriptive research describes and interprets what is concerned with conditions of relationships that exist; practices that prevail; beliefs; processes that are going on; effects that are being felt, or trends that are developing. The process of descriptive research goes beyond mere gathering and tabulation of data. It involves the elements or interpretation of the meaning or significance of what is described. Thus description is often combined with comparison and contrast involving measurements, classifications, interpretation and evaluation. [4]

\subsection{Population and Locale of the Study}

San Carlos City is the largest city of the province of Pangasinan. It has a population of 175,103 people. San Carlos City is politically subdivided into 86 barangays and Barangay Turac is one of its barangays. The main participants of the study are the 3 Barangay Officials and barangay workers, the President of Liga of the Barangay and DILG head in the municipality to have connection through implementation of the Barangay Management Information System for Cities and Municipalities in the Phillippines. Barangay Turac is located in the City of San Carlos, Province of Pangasinan. City hall is situated at Palaris St., San Carlos City, Pangasinan where documents/reports of the barangay submitted.

\subsection{Data Instrumentation}

The proponents will be using different data gathering tools, which can help to gather the relevant information needed in order to achieve the goal of the proposed study. Here are the data gathering tools:

Observation. The method involves watching and recording the behavior of individuals or groups, or the events that occur in a particular place. [5] The proponents will conduct observations to review the processes and activities involve in the barangay and city hall.

Interview. "An interview is a procedure designed to obtain information from a person's oral response to oral inquiries,". [6] The proponents will interview to gather and seek information. The proponents will conduct interview to the stakeholders including barangay captain, barangay workers, and assigned employee in city hall about the processes involved in issuing clearances and other services that the barangay issued to its constituents and the reports submitted by the barangay to the city hall.

Internet Research. Internet Research continues to provide an outlet for the publication of the latest research relating to internet technologies and applications, and their impact upon society. It is recommended reading for academics and practitioners alike, regularly providing material of interest and value to both communities. [7] The proponents will gather additional information through World Wide Web related to the study.

Library Research. A Library research begins when you need information to solve a problem, to fulfill an academic assignment or for your own purposes. It is a way of getting information by the use of books and journals (Ramsey, 2013). The proponents will also gather data by using books for the additional information needed in the study.

Survey Questionnaire. A very important aspect of research work is a survey or questionnaire. A questionnaire is usually composed of one or more questions, answered by a number of people. Survey is the used of asking questions to the respondents that is related to the study [8]. The proponents will provide survey to all the users of the system for them to comment or write what are the needs and don't to the system made by the proponent.

\subsection{Data Analysis}

The key model behind the Management Information System is to know the System Development Life Cycle (SDLC) Model for the development of study.

In order to create the Barangay Management Information System for San Carlos City, the proponents followed the appropriate rules of System Development Life Cycle (SDLC). This will serve as a guide to the proponents in their proposed system and its network infrastructure. Phases of the SDLC model includes System Planning, System Analysis, System Design, System Implementation, and System Support.

\section{PRESENTATION AND ANALYSIS OF DATA}

This method is a derivative of the traditional water fall model but with some minor variations relative to iterations between certain stages. In response to the perceived problems with the pure waterfall model, modified waterfall model have been introduced. This is the phases to overlap when needed. The modified waterfall can also split into subproject at an appropriate phase (such as after the hardware design and software design).In response to the perceived problems with the pure waterfall model, many modified waterfall models have been introduced. 
The main change is that the phases in this advanced model are permitted to overlap. Because the phases overlap, a lot of flexibility has been introduced. At the same time, a number of tasks can function concurrently, which ensures that the defects in the software are removed in the development stage itself and the overhead cost of making changes to the software before implementation is saved.

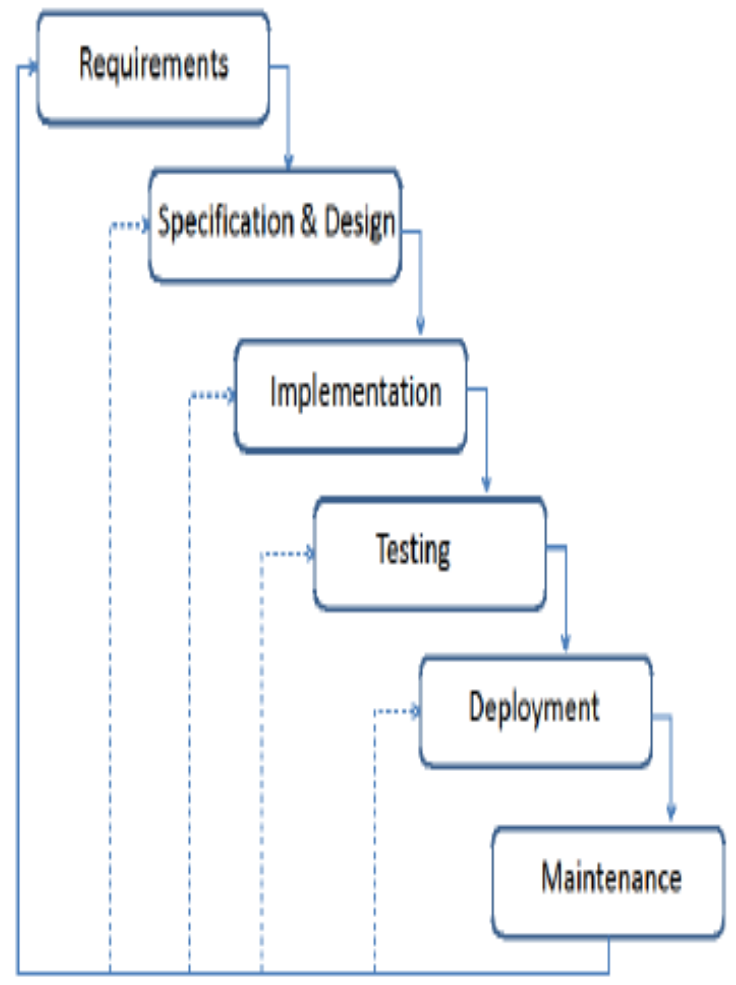

Fig 2: Modified Waterfall Model

\subsection{Model Comparison using the criteria}

Modified waterfall model uses the same phases as the pure waterfall model. In response to the perceived problems with pure waterfall model, modified waterfall model have been introduced. This enables the phases to overlap when needed. The modified waterfall can also split into subproject at an appropriate phase (such as after the hardware design and software design). In response to the perceived problems with the pure waterfall model.

\begin{tabular}{|l|c|c|c|c|c|}
\hline Criteria & Modified & $\begin{array}{c}\text { Iterative } \\
\text { Model }\end{array}$ & $\begin{array}{c}\text { Spiral } \\
\text { Model }\end{array}$ & $\begin{array}{c}\text { V- } \\
\text { Model }\end{array}$ & $\begin{array}{c}\text { Rapid } \\
\text { Application } \\
\text { Development } \\
\text { (RAD) Model }\end{array}$ \\
\hline $\begin{array}{l}\text { Speeding } \\
\text { access to } \\
\text { the } \\
\text { applicatio } \\
\text { ns and } \\
\text { service }\end{array}$ & 1 & 3 & 2 & 2 & 3 \\
\hline $\begin{array}{l}\text { Visibility } \\
\text { of the } \\
\text { stakehold } \\
\text { ers }\end{array}$ & 3 & 3 & 1 & 2 & 3 \\
\hline
\end{tabular}

\begin{tabular}{|l|c|c|c|c|c|}
\hline $\begin{array}{l}\text { Appropri } \\
\text { ate size } \\
\text { and } \\
\text { complexi } \\
\text { ty of the } \\
\text { software }\end{array}$ & 3 & 1 & 2 & 3 & 1 \\
\hline $\begin{array}{l}\text { Easy to } \\
\text { cope with } \\
\text { the } \\
\text { changes }\end{array}$ & 3 & 1 & 2 & 3 & 2 \\
\hline $\begin{array}{l}\text { Flexibilit } \\
\text { of the } \\
\text { system }\end{array}$ & 3 & 1 & 1 & 1 & 2 \\
\hline $\begin{array}{l}\text { Total } \\
\text { Average }\end{array}$ & 2.60 & 1.80 & 1.60 & 2.00 & 2.20 \\
\hline
\end{tabular}

Legend:

$\begin{array}{ll}2.51-3.00 & \text { - Excellent } \\ 2.01-2.50 & \text {-Very Good } \\ 1.51-2.00 & \text { - Good } \\ 1.00-1.50 & \text { - Poor }\end{array}$

\subsection{Implementation and Testing Phase}

This phase comes after a complete understanding of system requirements and specifications, it is the actual construction process after having a complete and illustrated design for the requested system. In this phase, the system is ready to be deployed and installed in customer's premises, ready to become running, live and productive, training may be required for end users to make sure they know how to use the system and to get familiar with it, the implementation phase may take long time and that depends on the complexity of the system and the solution it presents [9]. During the implementation, the proponents tested the system with the barangay captain and secretary, and Liga ng mga Barangay President. The proponents implement the system in the barangay hall and Liga ng mga Barangay office. After testing the system, the involve people accomplished a survey based on what they experience on the system. The proponents used convenience sampling method and come up with 70 respondents. Testing Phase includes detection of errors in the software. The testing process starts with a test plan that recognizes test-related activities, such as test case generation, testing criteria, and resource allocation for testing. The code is tested and mapped against the design document created in the design phase. The proponents conducted testing together with the barangay captain, appointed secretary, and the president of the Liga ng mga Barangay. The proponents summed up the comment of the tester.

\subsection{Deployment Phase}

After successful testing, the product is delivered / deployed to the customer for their use. As soon as the product is given to the customers, they will first do the beta testing. If any changes are required or if any bugs are caught, then they will report it in the engineering team. Once those changes are made or the bugs are fixed then the final deployment will happen. The proponents will not conduct this phase for this is beyond the scope and limitation. 


\subsection{Maintenance Phase}

The maintenance phase involves making changes to hardware, software, and documentation to support its operational effectiveness. It includes making changes to improve a system's performance, correct problems, enhance security, or address user requirements. To ensure modifications do not disrupt operations or degrade a system's performance or security, organizations should establish appropriate change management standards and procedures. The proponents will not conduct this phase for this is beyond the scope and limitation.

\section{CONCLUSION}

Therefore, the proponents conclude that the Barangay Management Information System for Cities and Municipalities in the Philippines, plays a big part to make work efficient. The gathered information like stakeholders, policies, IT equipment to be used, and barangay forms and reports are necessary inputs in the conduct of the study for they are means of getting the appropriate output of the study. Policies being practiced in the barangay and city hall are important factor in the determining its integrity and authority. Proponent also relied on the policies being practice in the barangay and city hall to be able to execute it on the proposed system. Since the functionalities of the system are very important, the proponents based it on the scope of the study where sending of reports was included in the process of the system. Modified Waterfall model met the criteria given by the proponents in choosing the best model to be use in the study. After comparing it to the other modes, it has been proven that it is suitable in the proponent's study. The full functionality of the proposed system met the scope of the study and ready to be used. The results of the survey exceeded the last objective of the study, which is to provide at least 90 $\%$ of acceptability of the system.

\section{RECOMMENDATION}

The proponents recommended that there should be a person that is computer literate to operate the system. This is important to run the system without any supervision. The proponents also encourage the stakeholders, to have further research of the same study in other places, local or foreign to verify, strengthen or contradict the findings of the study. This might be necessary so that if the findings of the study are all the same, the generalizations of wider application can be formulated. The proponents also recommend to provide their own I.T resources if they will adapt the study, in order to maintain the flow of the network infrastructure. These resources are essential to make daily operations organize and reliable.

\section{REFERENCES}

[1] Census of Population (2015). "Region I (Ilocos Region)". Total Population by Province, City, Municipality and Barangay. PSA. Retrieved 20 June 2016.

[2] Nestor, Lim. (2006). Barangay Management System. Retrieved May 25, 2016 from fics.upou.edu.ph/index.php/component/k2/item/34barangay-management-system/34-barangaymanagement-system

[3] Susan, Henczel. (2001). The Information Audit as a First Step Towards Effective Knowledge Management. Retrieved May 25, 2016 from https://www.degruyter.com/view/product/54021

[4] Hale, J. (2011). The 3 Basic Types of Descriptive Research Methods. Retrieved May 5, 2016 from http://psychcentral.com/blog/archives/the-3-basic-typesof-descriptive-research-methods

[5] Kenpro (2012). Observation Method. Retrieved at May 2, 2016 from www.kenpro.org

[6] Gary Dessler (n.d). What is interview? | Types of interviews. Retrieved May 2, 2016 from https://thebusinesscommunication.com/what-isinterview-types-of-interviews/

[7] Thomas Reuters, T. (2015). Internet Research. Retrieved May 2, 2016 from www.emeraldgrouppublishing.com

[8] Ryan, V. (2010). What is a Questionnaire? Retrieved from May 2, 2016 from www.technologystudent.com.

[9] Motea, A. (2015). What is System Development Life Cycle? Retrieved May 5, 2016 from https://airbrake.io/blog/insight/what-is-systemdevelopment-cycle. 